\title{
Growth pattern and Condition factor of Mangrove Crab (Scylla tranquebarica) in Segara Anakan Cilacap Regency
}

\author{
Sri Redjeki*, Retno Hartati, Hadi Endrawati, Widianingsih Widianingsih, Ria Azizah Tri \\ Nuraini, Ita Riniatsih, Elsa Lusia Agus and Robertus Triaji Mahendrajaya \\ Department Marine Sciences, Faculty of Fisheries and Marine Sciences, Diponegoro University \\ Jl. Prof. Sudharto, Tembalang, Semarang, Jawa Tengah
}

\begin{abstract}
Scylla tranquebarica is a species of mangrove crabs belong to family Portunidae, class Crustacea. The purpose of this research was to study population mangrove crab S. tranquebarica habitat in Segara Anakan Lagoon Cilacap Regency. The mangrove crabs were collected in April 2019 using bubu trap as fishing gear. Sampling was carried out in Klace, Sapuregel and Panikel area. The growth pattern for mangrove crab in the Sapuregel area was allometric negative both for males $(b=2.27)$ and females $(b=2.28)$. But for Panikel village area, the growth pattern for males was allometric negative $(b=2.67)$, while for females it was allometric positive $(b=3.95)$. In the Panikel area, the average value for the condition factor was $1.456 \pm 0.65$. Additionally, in the Sapuregel area the average value of Condition factor was $1.004 \pm 0.09$.
\end{abstract}

\section{Introduction}

Scylla transquebarica is mangrove crab belonged to family Portunidae, class Crustacea [1,2]. Most of the mangrove crabs are common in the habitat of the mangrove ecosystem in the coastal area [3,4]. Mangrove crabs have an important role in the benthic ecosystem in the mangrove area [5]. Mangrove crab (Scylla sp.) spends most of its life in the mangrove ecosystem as the main habitat for feeding ground, nursery ground, shelter and growth. The mangrove ecosystem is considered the ideal habitat for mangrove crab. Young mangrove crabs are carried by tidal currents and attaches to the mangrove roots to take refuge. Adult mangrove crabs is a permanent resident of mangrove forests that usually immerse themselves in mud substrates or dig holes on soft substrates to hide[5].

The decline in the mangrove crab population will undoubtedly disrupt the mangrove ecosystem. The amount of demand has resulted in the capture of mangrove crabs from natural stocks in coastal waters, especially in the mangrove or estuary region[6]. Recently, the increasing economic value of mangrove crab fisheries has increased the capture of mangrove crabs. The average growth rate of mangrove crabs in several major producing provinces is rather slow and tends to decline [6]. The decline in mangrove crab population occurs due to the devastation of mangrove forests. Declining mangrove forest area in Segara Anakan has

*Corresponding author: sriredjekikelautan@gmail.com 
impacted the population of various types of benthic animals such as mangrove crabs (Scylla sp.), Totok shells (Geloina sp.), various types of gastropods, crustaceans and other types of organisms that have economic value[6].

In Java, the impact of the high sediment load on the coastal area is undeniable, especially in the Segara Anakan Lagoon [7,8]. Mangrove ecosystems in Segara Anakan are experiencing changes in function caused by reduced mangrove forest area, land-use change, sedimentation, and illegal logging. This causes disturbance to the habitat of benthic organisms, especially mangrove crabs. Hence, it is necessary to study the population and bioecology of mangrove crabs in Segara Anakan. The purpose of this study was to determine the population of mangrove crabs in Segara Anakan Lagoon.

This research is expected to be useful as a source of information to determine the condition of Scylla sp mangrove crab populations and their bioecological conditions in the Segara Anakan mangrove forest. Furthermore, this research can also be used as a reference in the management of aquatic resources, especially mangrove crabs (Scylla sp.) as a sustainable conservation effort.

\section{Materials and Method}

The study sites were in Klaces, Panikel and Sapuregel village in the Segara Anakan area in Cilacap, Central Java (Figure 1). Scylla transquebarica samples were collected using baited traps in Panikel, Klaces and Sapuregel areas in April 2019. Traps were used as many as 90 and sampling were done for 2 trips. 30 traps were installed in the morning and evening for each area.

The measured water quality consisted of $\mathrm{pH}$, Salinity, and Dissolved Oxygen using water quality checker. Sediment samples were taken using hand corer. Water samples for nitrate and phosphate measurements were taken using Nansen bottle.

Samples of mangrove crabs were measured, including carapace width, length, and individual total weight. Genders were distinguished based on primary sexual characteristics. Data were analyzed descriptively by presenting graphs and tables. Chi-square test was performed to determine whether the data distribution was normal or not with SPSS analysis. The data obtained were analyzed to obtain information on the relationship between length and weight and condition factors in each sex. The relationships of carapace length and weight for female and male total were analyses using least square regression.

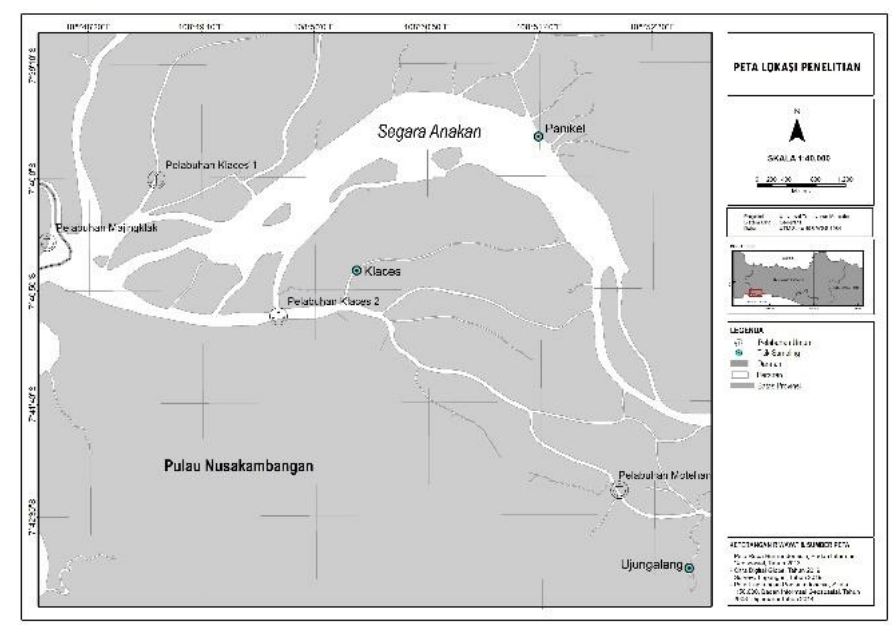

Fig 1. Location site of sampling Scylla transquebarica in Segara Anakan Lagoon, Cilacap, 


\section{Results and Discussion}

\subsection{Results}

\subsubsection{Environmental Parameters}

The results of measurements of environmental parameters at Klaces and Panikel and Sapuregel stations showed that the salinity values in the range of 0 to $7 \mathrm{ppt}$ and depth values in the range of $10-20 \mathrm{~cm}$ (Table 1.). The value of the phosphate had range 0.0631-0.1003 mg.L $\mathrm{L}^{-1}$ (Table 1). According to the result, the Segara Anakan Lagoon ecosystem including its canals, rivers, and estuaries provided silt clay (muddy) substrate (Table 1), which acts as a significant habitat, shelter and nursery ground for commercially important mangrove crab species. Water quality results showed that the waters still supported the life of mangrove crabs (S. tranquebarica) in the Segara Anakan Lagoon.

Table 1. Parameter of water quality in Klaces, Panikel and Sapuregel area, Segara Anakan Cilacap in April 2019

\begin{tabular}{lccc}
\hline Water quality parameters & Klaces & Panikel & Sapuregel \\
\hline Salinity $(\mathrm{ppt})$ & $5-7$ & $0-5$ & $0-5$ \\
DO $(\mathrm{ppm})$ & $6,45-6,74$ & $6.78-7.82$ & $6.47-7.65$ \\
Temperatur $\left({ }^{\circ} \mathrm{C}\right)$ & $28-28.7$ & $29-30.80$ & $29.5-30.5$ \\
pH & $5-6.8$ & $6-7.4$ & $6-7.5$ \\
Phosphate $\left(\mathrm{mg} . \mathrm{L}^{-1}\right)$ & 0,1003 & 0.0631 & 0.0835 \\
Nitrate $\left(\mathrm{mg} . \mathrm{L}^{-1}\right)$ & 0.5737 & 0.2112 & 0.3651 \\
Depth $(\mathrm{cm})$ & 10 & 20 & 10 \\
Type of substrate & Silt clay & Silt clay & Slit clay \\
\hline
\end{tabular}

\subsubsection{Morphological Mangrove Crab (S. transquebarica)}

According to the result, S. transquebarica found in the Panikel area (32 ind) were larger than those in the Klaces and Sapuregel (Fig 2). The number of S. transquebarica caught in Sapuregel was 31 individuals and for $S$. serrata species was 14 individuals. Similarly, for the observation area in Klaces $S$. transquebarica, 4 individuals was caught and for S. serrata species was 17 individuals. While in Klaces, 17 individuals of $S$. serrata was found.

In the Klaces, the average total weight of Scylla transquebarica was $223 \pm 5.89$ gram, the average carapace length was $7.13 \pm 0.096 \mathrm{~cm}$ and the average carapace width was $9.98 \pm 0.15$ $\mathrm{cm}$. Furthermore, at the Panikel area, the average total weight of Scylla transquebarica was $205 \pm 78.35$ gram, the average carapace length was $7.11 \pm 1.06 \mathrm{~cm}$ and average carapace width was $9.95 \pm 1.32 \mathrm{~cm}$. Additionally, at the Sapuregel area, the average total weight was $168 \pm 62.87$ gram, the average carapace length was $6.36 \pm 1.05 \mathrm{~cm}$ and the average carapace weight was $8.80 \pm 1.45 \mathrm{~cm}$. (Fig. 3, 4 and 5). According to Chi-Square test, distribution for total weight of $S$. transquebarica in the Panikel area was normal $\left(\lambda^{2}\right.$ count $=5.38 ; \mathrm{df}=25 ; \lambda^{2}$ table $=44.31 \mathrm{P}=0.01)$. Furthermore, the distribution for total weight of $S$. transquebarica in the Sapuregel was normal $\left(\lambda_{\text {count }}^{2}=2.97 ; \mathrm{df}=26 ; \lambda_{\text {table }}^{2}=45.64 ; \mathrm{P}=0.01\right)$.

According to analyses, mangrove crabs caught in Sapuregel (6.36) have smaller carapace length than Klaces and Panikel (Fig. 3). Additionaly, mangrove crabs caught in Sapuregel $(8.80 \mathrm{~cm})$ have smaller carapace width than Klaces and Panikel (Fig. 5). Furthermore, distribution data for carapace length of $S$. transquebarica in the Panikel area was normal distribustion $\left(\lambda_{\text {count }}^{2}=7.38 ; \mathrm{df}=20 ; \lambda^{2}\right.$ table $\left.=37.57 ; \mathrm{P}=0.01\right)$. The distribution data for 
carapace length of $S$. transquebarica in the Sapuregel was normal distribution $\left(\lambda^{2}\right.$ count $=7.07$; df $=19 ; \lambda^{2}$ table $=36.19 ; \mathrm{P}=0.01$ ).

Additionaly, mangrove crabs caught in Sapuregel $(8.80 \mathrm{~cm})$ have smaller carapace width than Klaces and Panikel (Fig. 5). In the Panikel area, carapace width for S. transquebarica has normal distribution $\left(\lambda_{\text {count }}^{2}=10.5 ; \mathrm{df}=19 ; \lambda_{\text {table }}^{2}=36.19 ; \mathrm{P}=0.01\right)$. Likewise, the distribution data in the Sapuregel area showed that the data was normally distributed $\left(\lambda^{2}\right.$ count $=8.032 ; \mathrm{df}=21 ; \lambda^{2}$ table $=38.93 ; \mathrm{P}=0.01$ ).

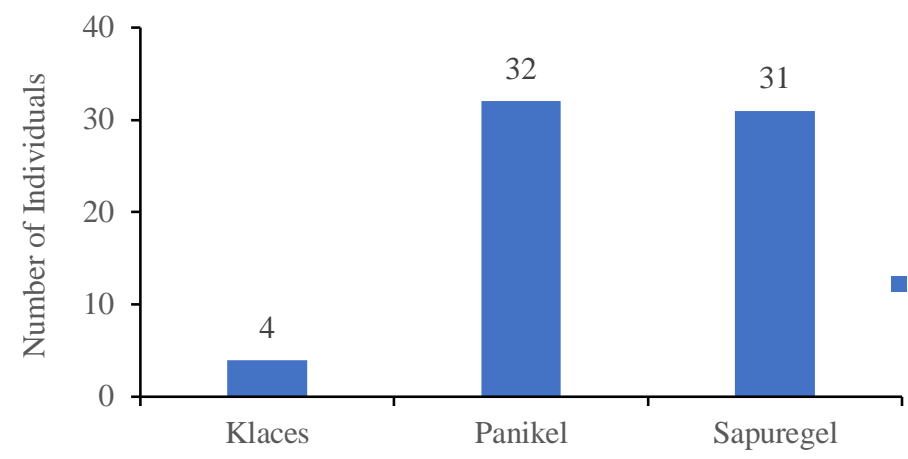

Fig. 2. The number of mangrove crabs $S$. transquebarica caught at the location in Segara Anakan Lagoon.

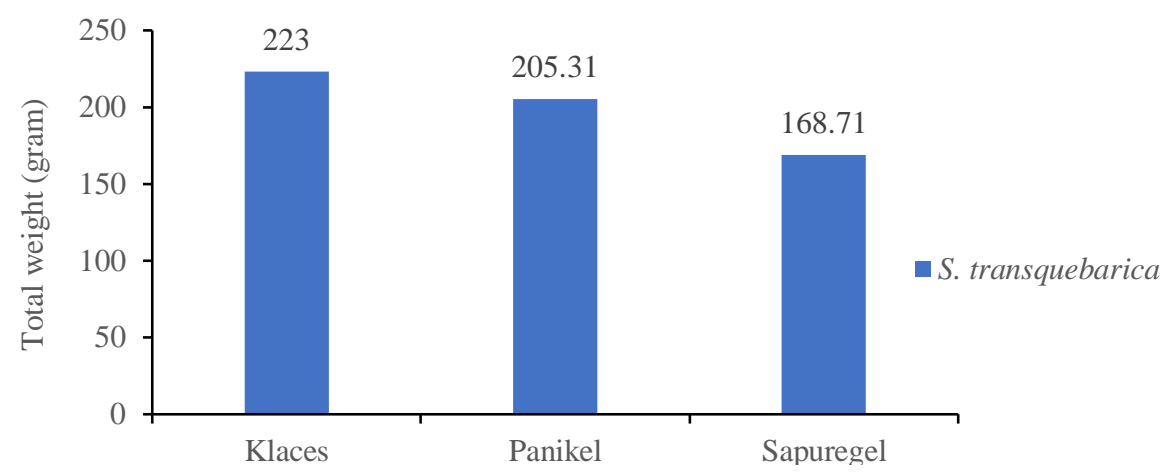

Fig. 3. The Average total weight of Scylla transquebarica in Segara Anakan

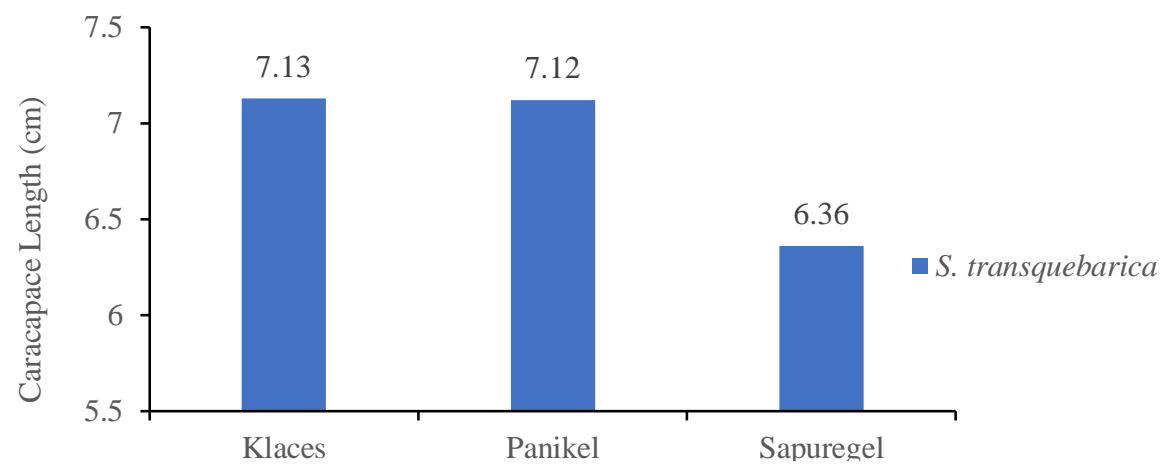

Fig. 4. The Average carapace length (cm) of Scylla transquebarica in Segara Anakan, Cilacap 


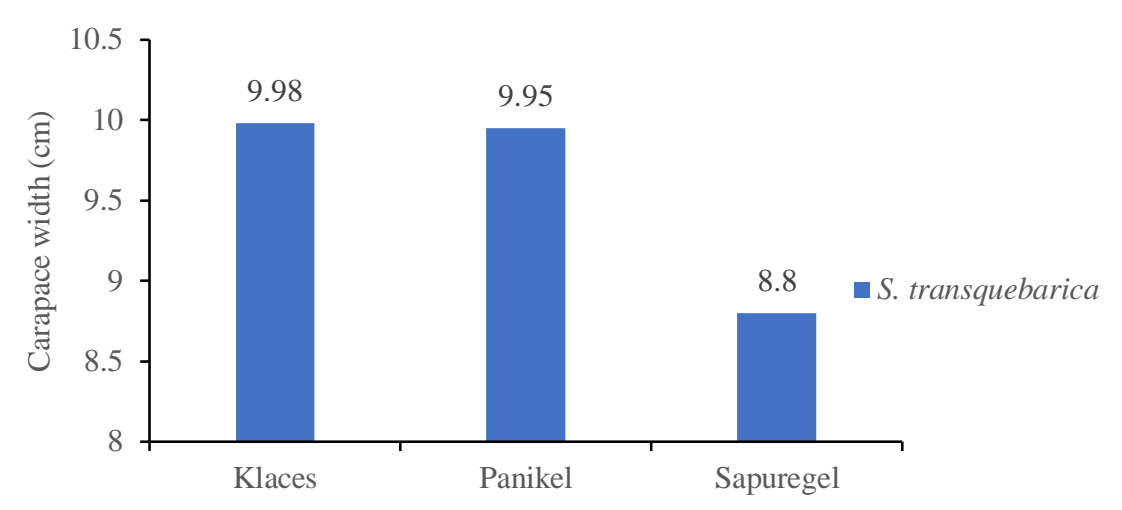

Fig. 5. Average Carapace width (cm) S. transquebarica in the Segara Anakan Lagoon.

\subsubsection{Growth pattern and Condition factor}

The relationship between carapace width and total weight were analyzed using least square regression. According to the result that total weight for females increased faster than males $\left(\mathrm{Wm}=0.4419 \mathrm{~L}^{2.67}\right.$ for males and $\mathrm{W}_{\mathrm{f}}=0.019 \mathrm{~L}^{3.9527}$ for females) (Figure 6). The growth pattern for $S$. tranquebarica males in the Panikel area was allometric negative $(b<3)$. While the growth pattern for females $S$. tranquebarica was allometric positive (b>3) (Fig. 6).

The total weight for males increased faster than females $\left(\mathrm{Wm}=0.4419 \mathrm{~L}^{2.6721}\right.$ for males and $\mathrm{Wf}=0.019 \mathrm{~L}^{3.9527}$ for female). (Fig. 7.) The growth pattern for female and male $S$. tranquebarica in the Sapuregel area was allometric negative $(b<3)$. However, the recruitment process of the $S$. tranquebarica population in the Sapuregel area was still growing. This was evident by the discovery of the size of a small mangrove crab carapace.

In the Panikel area, the condition factor for $S$. transquebarica was $1.053 \pm 0.299$. Furthermore, in the Sapuregel area, the condition factor for S. transquebarica was 1,012 \pm 0.148 .

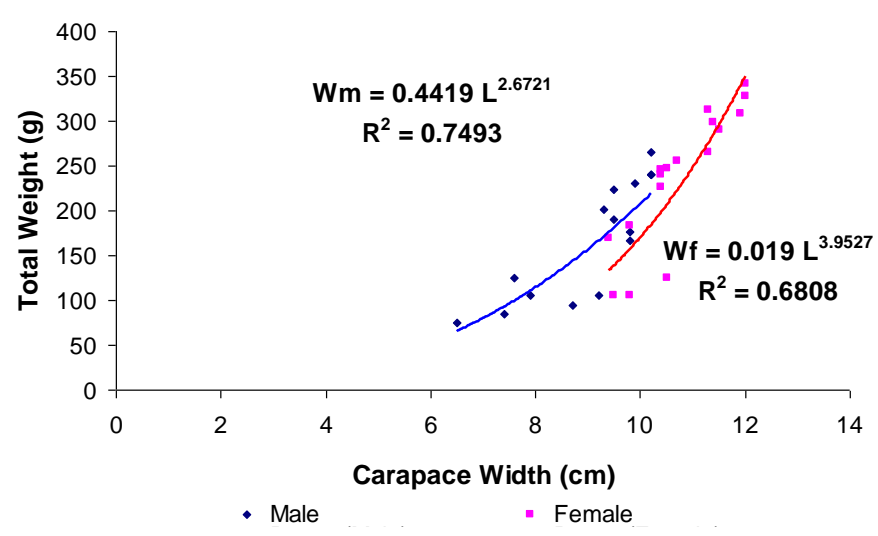

Fig. 6. The relationship between carapace width and total weight S. tranquebarica in the Panikel area, Segara Anakan. 


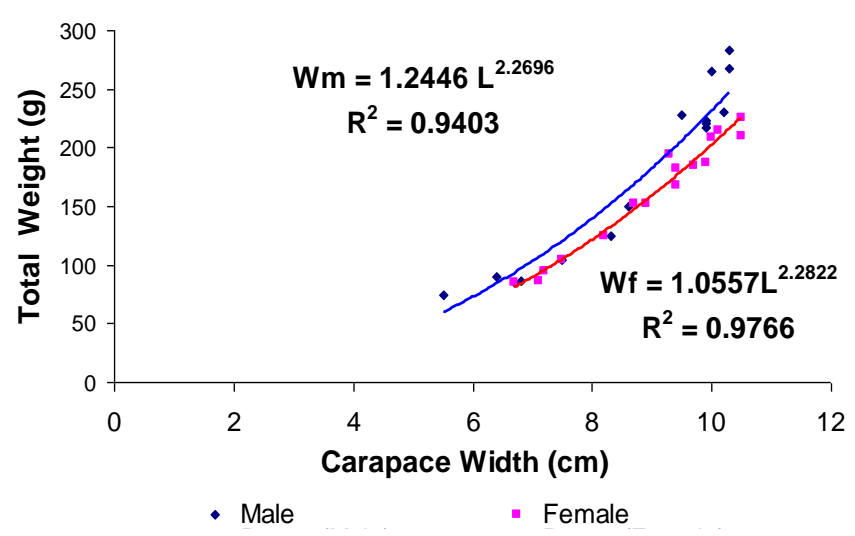

Fig. 7. The relationship between carapace width and total weight $S$. tranquebarica in the Sapuregel area, Segara Anakan.

\subsection{Discussion}

The average temperature in three areas (Klaces, Panikel, and Sapuregel) was around 28$30.8^{\circ} \mathrm{C}$. Fujaya et al. (2012) [9] previously found that the optimum temperature for the growth of mangrove crabs is $25-35^{\circ} \mathrm{C}$. Temperature is one of the important factors that influence the activity, survival, growth, and molting of mangrove crabs. According to Shelley and Lovatelli (2011) [10], the optimal temperature affected the survival of the Mangrove Crab. Phelan and Grubert (2007) [11] stated that higher temperatures accelerated growth and reduced the time needed to reach the maturity of mangrove crab gonads.

The average salinity value of the measurement results of 3 observation sites had a range of 0 - 7 ppt. Mangrove crabs can still live in the range of $5-40 \mathrm{ppt}[10,12]$. Mangrove crabs are euryhaline or can live with a wide range of salinity. That mangrove crabs of $S$. tranquebarica for all size classes were seen to spread well at all research stations in the Cibako Sancang mangrove forest area of Garut Regency[13]. This means that this species has a great tolerance for changes in water salinity so that it can live in a wide area.

The results of measurements of the average $\mathrm{pH}$ at the three observation locations ranged from 5-7.5. Klaces area has a lower $\mathrm{pH}$ compared to Panikel and Sapuregel area. This was because mangrove crabs were able to live in acidic water conditions, namely in mud substrate areas with an average $\mathrm{pH}$ of 6.5 [14]. This was also in accordance with the condition of the observation site which is dominated by mud clay.

The condition of the habitat and mangrove ecosystem strongly supported the growth of the mangrove crab population. This can be seen from the large size of mangrove crabs caught during the study. The greater the density of mangroves, the greater the number of mangrove crabs caught. The number of $S$. transquebarica captured in the Panikel was 32 individuals and in Sapuregel by 31 individuals. Whereas in Klaces there were $4 \mathrm{~S}$. transquebarica individuals and 17 individuals for $S$. serrata. The number of $S$. transquebarica captured in Panikel and Sapuregel is higher than the range of $S$. transquebarica captured in the Village of Tanjung Rejo, Regency of Deli Serdang had range of 10-19 individuals from three sampling locations [15] As for the Cibako Sancang Garut Regency mangrove forest area, there were 55-70 individuals $S$. transquebarica found in 16 sampling times (August November 2011) in three locations[13].

At Panikel and Sapuregel area, the average carapace width was $9.95 \pm 1.32 \mathrm{~cm}$ and 8.803 $\pm 1.45 \mathrm{~cm}$. Klaces area, the location with only 4 individuals of $S$. transquebarica found, has an average carapace width of $9.98 \pm 0.15 \mathrm{~cm}$. These measurements were in accordance with 
previous research conducted by Robertson and Kruger at Natal, South Africa where the size of the average carapace width for maturity size was more than $9 \mathrm{~cm} \mathrm{[16].} \mathrm{The} \mathrm{size} \mathrm{of} \mathrm{the}$ captured mangrove crab indicated that the population of $S$. transquebarica in the Klaces, Panicles and Sapuregel area was growing and developing well. This can be seen from the value of the growth pattern.

The relationship between male and female carapace width to total weight was analyzed using least square regression. In the Panikel area, the relationship suggested that females increased in total weight faster than males $\left(\mathrm{Wf}=0.019 \mathrm{~L}^{3.95}\right.$ for females and $\mathrm{Wm}=0.442$ $\mathrm{L}^{2.67}$ for males). The total weight of females was larger than males which suggested that females already have matured gonad. The results were consistent with the previous research in the tropic region, where mangrove crabs become sexually mature at a smaller size in the tropics than in the subtropics especially in African and Australian shore [17]. Additionally, in the Sapuregel area, the males increased in weight in similarly with the females $(\mathrm{Wm}=$ $1.245 \mathrm{~L}^{2.27}$ for males and $\mathrm{Wf}=1.056 \mathrm{~L}^{2.28}$ for females).

The growth pattern of the mangrove crabs was found to be different at the sampling locations. At the Sapuregel area, both the male and the females of S. transquebarica had growth pattern with negative allometric $(\mathrm{b}=2.28, \mathrm{~b}<3)$. At the Panikel area, males of $S$. transquebarica had a negative allometric (2.67) and the females had a growth pattern with positive allometric $(b=3.95)$. The results were found to be opposite with the previous study conducted by Dewantara et al (2017) [18] in the West Part of Segara Anakan Estuary, where the males of $S$. transquebarica had an isometric growth pattern and the females had a negative allometric. The negative allometric growth pattern of $S$. transquebarica occurred because the mangrove crab required more food intake for molting and gonad maturation process. The molting process of female mud crab will lead to the copulation process; as a result, the female mud crab grows more on their carapace width. The molting process was less common in male mangrove crab; therefore, food intake tends to be absorbed to lengthen and enlarge the claws (chelae) which hold an important role in the mating process [6].

Condition factors can be interpreted as the level of fatness from mangrove crabs due to the influence of environmental factors that can affect the growth and development of mangrove crabs. The condition factor for S. transquebarica caught in Sapuregel (1,004 \pm $0.09)$ is smaller than $S$. transquebarica caught in Panicles $(1,456 \pm 0.65)$.

The difference in mangrove crab growth was presumably influenced by the differences in its environmental conditions; e.g. level of competition for food and space, food availability, average water, $\mathrm{pH}$, temperatures and salinity contributing to its growth rate.

\section{Conclusion}

The mangrove crab (S. tranquebarica) dominated the Panikel and Sapuregel regions. In the Sapuregel, S. tranquebarica have a smaller total weight and carapace size than in the Panikel and Klaces area. This means that the mangrove crab population in Sapuregel is still in its growth stage. In Sapuregel, male mangrove crabs have faster total weight growth than females. Meanwhile in Panikel, female mangrove crab ( $S$. tranquebarica) have faster total weight than male. In the Sapuregel, the males and females $S$. tranquebarica had a negative allometric growth pattern. Whereas, in the Panikel area, the males of S. transquebarica had negative allometric and the females had positive allometric. The condition factor in the Panikel area was higher than in the Sapuregel.

This research was funded by the Faculty of Fisheries and Marine Sciences of UNDIP through a Research grant. No. 79/UN7.5.10/HK/2019. We would like to thank all those who have helped in this research. 


\section{References}

1. C. P. Keenan, \& A. Blackshaw. Mud crab aquaculture and biology-proceedings of an international scientific forum held in Darwin, Australia. in ACIAR Proc vol. 78216 (1997).

2. K. E. Carpenter, \& V. H. Niem. FAO species identification guide for fishery purposes. The living marine resources of the Western Central Pacific. Volume 6. Bony fishes part 4 (Labridae to Latimeriidae), estuarine crocodiles, sea turtles, sea snakes and marine mammals. (2001).

3. M. E. Hoq. Sundarbans mangrove: fish and fisheries ecology, resources, productivity and management perspectives. Graphic Media, Dhaka, Bangladesh vol. 271 (2008).

4. A. Rouf, S. I. Shahriar, G. Sarower, \& N. Ahsan. Taxonomic clarification of mud crab species of genus Scylla (Brachyura: Portunidae) available in the Coastal Regions of Bangladesh. Asian Fish. Sci. 29, 124-136 (2016).

5. L. Siahainenia. Bioekologi kepiting bakau (Scylla spp) di ekosistem mangrove Kabupaten Subang Jawa Barat.[Dissertation]. Sekolah Pascasarjana IPB. Bogor (2008).

6. N. I. Wijaya, F. Yulianda, M. Boer, \& S. Juwana. Biologi Populasi Kepiting Bakau (Scylla serrata F.) Di Habitat Mangrove Taman Nasional Kutai Kabupaten Kutai Timur. Oseanologi dan Limnol. di Indones. 36, 443-461 (2010).

7. J. Heyde, M. C. Lukas, \& M. Flitner. Pembayaran Jasa Lingkungan: Instrumen baru untuk mengatasi masalah berkepanjangan di daerah aliran sungai dan pesisir di Indonesia. (2017).

8. M. C. Lukas. Widening the scope: linking coastal sedimentation with watershed dynamics in Java, Indonesia. Reg. Environ. Chang. 17, 901-914 (2017).

9. Y. S. Fujaya, S. Aslamyah., L. Fudjaja, dan N. Alam. Budidaya dan Bisnis Kepiting Lunak Stimulasi Molting dengan Ekstrak Bayam. Brilian Internasional. Surabaya. (2012)

10. C. Shelley, \& A. Lovatelli. Mud crab aquaculture: a practical manual. FAO Fish. Aquac. Tech. Pap. I (2011).

11. M. Phelan, \& M. Grubert. The Life Cycle of the Mud Crab. Fishnote No: 11.Coastal Research Unit, Department of Primary Industry, Fisheries and Mines. Northern Territory Government of Australia. Darwin. (2007)

12. D. Sulastini. Seri Buku Informasi dan Potensi Mangrove Taman Nasional Alas Porwo. Balai Taman Nas. Alas Purwo. Bayuwangi (2011).

13. I. Avianto, S. Sulistiono, \& I. Setyobudiandi. Karakteristik Habitat Dan Potensi Kepiting Bakau (Scylla serrata, S. transquaberica, and S. olivacea) di Hutan Mangrove Cibako, Sancang, Kabupaten Garut Jawa Barat. Aquasains 2, 97-106 (2013).

14. R. Chairunnisa. Kelimpahan kepiting bakau (Scylla sp.) di kawasan hutan mangrove KPH Batu Ampar, Kabupaten Pontianak, Kalimantan Barat. Fakultas Perikanan dan Ilmu Kelautan, Institut Pertanian Bogor (2004).

15. T. N. Manalu, Y. Djayus, \& R. Leidonald. Hubungan Kerapatan Mangrove Terhadap Kelimpahan Kepiting Bakau (Scylla spp.) Di Desa Tanjung Rejo Kecamatan Percut Sei Tuan Kabupaten Deli Serdang Provinsi Sumatera Utara Jurnal Aquacoastmarine 12(2), 1-14. (2016)

16. W. D. Robertson, \& A. Kruger. Size at maturity, mating and spawning in the portunid crab Scylla serrata (Forskål) in Natal, South Africa. Estuar. Coast. Shelf Sci. 39, 185200 (1994). 
17. N. J. Quinn, \& B. L. Kojis. Reproductive biology of Scylla spp.(Crustacea: Portunidae) from the labu estuary in Papua New Guinea. Bull. Mar. Sci. 41, 234-241 (1987).

18. W. Dewantara, Sulistiono, \& Zairion. Growth of Mud Crab (Scylla tranquebarica Fabricus, 1798) in the Estuary of West Segara Anakan, Cilacap, Indonesia. International Journal of Sciences: Basic and Applied Research (IJSBAR). 36(2): 202-217 (2017) 